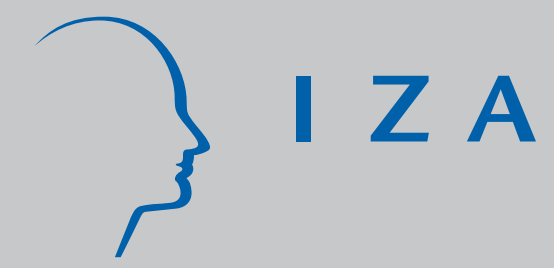

IZA DP No. 23

\title{
Learning Efficiency of Economics Students
}

\section{Klaus F. Zimmermann}

Thomas K. Bauer

September 1998 


\title{
LEARNING EFFICIENCY OF ECONOMICS STUDENTS
}

\author{
Thomas Bauer \\ Klaus F. Zimmermann
}
Discussion Paper No. 23
September 1998

\author{
IZA \\ P.O. Box 7240 \\ D-53072 Bonn \\ Germany \\ Tel.: +49-228-3894-201 \\ Fax: +49-228-3894-210 \\ Email: iza@iza.org
}

This Discussion Paper is issued within the framework of IZA's research area General Labor Economics. Any opinions expressed here are those of the author(s) and not those of the institute. Research disseminated by IZA may include views on policy, but the institute itself takes no institutional policy positions.

The Institute for the Study of Labor (IZA) in Bonn is a local and virtual international research center and a place of communication between science, politics and business. IZA is an independent, nonprofit limited liability company (Gesellschaft mit beschränkter Haftung) supported by the Deutsche Post AG. The center is associated with the University of Bonn and offers a stimulating research environment through its research networks, research support, and visitors and doctoral programs. IZA engages in (i) original and internationally competitive research in all fields of labor economics, (ii) development of policy concepts, and (iii) dissemination of research results and concepts to the interested public. The current research program deals with (1) mobility and flexibility of labor markets, (2) internationalization of labor markets and European integration, (3) the welfare state and labor markets, (4) labor markets in transition, (5) the future of work, and (6) general labor economics.

IZA Discussion Papers often represent preliminary work and are circulated to encourage discussion. Citation of such a paper should account for its provisional character. 
IZA Discussion Paper No. 23

September 1998

\author{
ABSTRACT \\ LEARNING EFFICIENCY OF \\ ECONOMICS STUDENTS*
}

Using a stochastic frontier approach this paper evaluates the effects of substantial changes in the teaching material on students learning efficiency. The results indicate that the main effects of the re-organization on the learning efficiency was a decreasing importance of students' attendance and of continuous preparation of the material.

JEL Classification: A22

Keywords: efficiency, education of economics, stochastic frontier

Klaus F. Zimmermann

IZA

P.O. Box 7240

D - 53072 Bonn

Germany

Tel.: +49-228-3894-201

Fax: +49-228-3894-210

email: Zimmermann@iza.org

\footnotetext{
* We would like to thank Ira Gang, Regina Riphahn, Felix Ritchie, Ralph Rotte, Anja Thalmaier and Francis Vella for helpful comments and suggestions. Thomas Bauer gratefully acknowledges financial support of the Alexander-von-Humboldt Foundation.
} 


\section{Introduction}

For a long time the literature in the economics of education has attempted to identify the determinants of students' performance in economics. (See Siegfried and Fels, 1979, Becker, 1997, and Becker et al., 1990, for an overview of this literature.) Among other potential determinants, researchers have analyzed the effects of students' and teachers' ability (Watts and Bosshardt, 1991), sex and race (Durden and Ellis, 1995, Ferber et. al., 1983, Lumsden and Scott, 1987, Williams et. al., 1992), attendance (Romer, 1993, Schmidt, 1983), teaching technology and class size (Lopus and Maxwell, 1995).

This paper departs from the existing literature in two respects. First, using data for two semesters collected in a lecture on the principles of macroeconomics and the connected exercise courses for undergraduate students of the University of Munich in Germany, we try to evaluate the effects of re-organizing the lecture and the courses on students performance. Besides a reduction in the contents and a change in the order of the presentation of the topics of the lecture, the main change between the two semesters has been the preparation of a new exercise book (Bauer and Zimmermann, 1997) with very detailed answers to problem sets. Before the introduction of this book the students could rely only on the help of a standard macroeconomic textbook and the notes they made in the lecture and during the exercise courses.

Second, most of the existing studies on students' performance used ordinary least squares to estimate the parameters of interest like changes in teaching technologies. In this paper we want to follow a different approach. Using a stochastic frontier approach, which has been developed by Aigner 
et. al. (1977), we want to evaluate the effects of the described changes in the macroeconomics course on the learning efficiency of the students. In particular, the stochastic frontier approach enables us to study whether the introduction of an exercise book affects the deviation of the points the students actually received in the final exam from a potential maximum amount the students could have achieved given their characteristics.

The outline of the paper is as follows. In the next section we provide a short description of the macroeconomic lecture for undergraduates at the University of Munich and of the data, which have been collected in this lecture during summer and winter 1996. Section 3 presents the econometric framework. The estimation results will be discussed in Section 4. Section 5 concludes.

\section{The Data Base}

One of the compulsory lectures for undergraduate students at the University of Munich with their majors in business, economics and economics teaching, as well as students with other majors who study economics voluntary, is principles of macroeconomics. This course consists of one lecture of 2 hours per week which has been taught by the second author since 1989 and eight different exercise courses of 4 hours per week which were taught by different graduate students of the faculty of economics. In order to re-organize the lecture and the courses, a survey of the students was carried out in the last week of July, 1996, to obtain information regarding the improvement in teaching principles of macroeconomics. Another objective of the survey was the construction of a database for the evaluation of the main determinants of the performance of the students in the final exam at the 
end of August, 1996. In the following semester the survey was repeated to evaluate the effects of the re-organization of the lecture and the courses on students' performance.

To assess the effects of the re-organization on students' learning efficiency we assume an economics learning production function. The learning output is measured using the number of points a student received in one of the final exams of the two semester. The points the students received in the final exams were merged with the respective surveys using the student-ID. It should be noted that the final exams were very similar in their structure and contents. In both exams the students had to answer 4 open questions with 3 sub-questions within 120 minutes. The students could receive a maximum of 120 points. In the summer 1996 the best student reached a maximum of 95 points; in the winter 1996/97 the best student obtained 102 points.

As inputs in the learning production function we consider: 1) a dummy variable indicating whether the student took the lecture voluntarily (Macro Voluntary); 2) a vector of measures of the attendance of students in the lecture and courses (Missed Lectures, Missed Courses);3) proxies of the learning strategy including whether the student did not review his lecture and course notes (Never Reviewed Lecture Notes, Never Reviewed Course Notes), respectively, and whether the students learned in a group (Team-work); 4) the high school grade of the student, which ranges from the highest grade 0.7 to the worst grade 3.8 , to proxy students' ability; 5) the number of exams the student planned to take in the respective semester (Number of Exams) to control for the students' learning strain; 6) the number of semesters the course instructor of a student has already taught a course in principles of macroeconomics (Instructors Experience) to proxy for teaching ability; and 7) a vector 
of variables of the socioeconomic background of a student including his/her gender (Female) and whether the student had to work during the semester (Worked during Semester) to finance his/her university education.

Table 1 provides descriptive statistics of the variables employed in the study. After excluding all observations with missing values in one of the used variables a total sample of 421 observations was available of which 205 observations are from the summer survey and 216 observations are from the winter survey. Most of these variables do not vary much between the two semesters. For the majority of the students $(98 \%)$ the course is compulsory. One third of the students are females and about two thirds have to work during the semester to finance their study. On average, the students had planned to write three final exams, and the average high school grade is 2.3 .

Remarkable differences between the two semesters appear with regard to students attendance and learning strategies. Whereas over $65 \%$ of the students missed one of the lectures in the summer, this number drops to $39 \%$ in the winter. One could argue that student absenteeism is usually higher in the summer because they allocate more time to leisure. But this argument does not hold for the courses, since only $19 \%$ missed a course in the summer but nearly $44 \%$ in the winter. These numbers suggest that the re-organization changed the attendance behavior of students by increasing the attractiveness of the lecture and increasing absenteeism in the courses. The latter could be due to the introduction of the exercise book. Furthermore, Table 1 indicates that the re-organization of the lecture and the courses also changed the learning strategy of the students. The number of students never reviewing their lecture notes dropped from $79 \%$ in the summer to $23 \%$ in the winter. A smaller 
influence was observed for the courses where the number of students who never reviewed their course notes dropped only by about 1 percentage point from $14 \%$ in the summer to $13 \%$ in the winter. A similar pattern was found for the number of students learning in groups. Whereas $24 \%$ of the students formed learning teams in the summer this number drops to $19 \%$ in the winter. This decrease may also be attributed to the exercise book, since the detailed solutions in this book makes discussions about problems less important. Finally, since some of the older graduate students who finished their dissertation and left the university have been replaced by younger graduates, the average experience of the course instructors dropped from nearly 5 semester in the summer to 3 semester in the winter.

\section{Econometric Framework}

Students' learning efficiency is analyzed using a stochastic production frontier approach which has been introduced by Aigner et al. (1977). A recent overview of this approach to estimate production efficiency is given by Greene (1993). We assume the following education production frontier

$$
Y_{i}=f\left(\beta^{\prime} X_{i}\right)+u_{i}-v_{i}
$$

where $Y_{i}$ denotes the logarithm of the number of points student $i$ has received in the final exams, $X_{i}$ is a vector of the inputs discussed in the previous chapter, $u_{i}$ is a symmetric error which is normally distributed with mean 0 and constant variance $\sigma_{\mathrm{u}}$, and $\mathrm{v}_{\mathrm{i}}$ is a nonnegative error which is assumed to be exponentially distributed, i.e. $f\left(v_{i}\right)=\theta e^{-\theta v_{i}}$, where $\theta$ is the parameter to be estimated. For this model, the log-likelihood to be maximized is (see Greene, 1993) 


$$
1\left(\beta, \sigma_{\mathrm{u}}, \theta\right)=-\mathrm{N}\left[\ln \theta+\frac{1}{2}\left(\theta \sigma_{\mathrm{u}}\right)^{2}\right]+\sum_{\mathrm{i}}\left[\ln \Phi\left(\frac{-\varepsilon_{\mathrm{i}}}{\sigma_{\mathrm{u}}}-\theta \sigma_{\mathrm{u}}\right)+\theta \varepsilon_{\mathrm{i}}\right],
$$

where $\Phi($.$) is the cumulative distribution function of the standard normal distribution and \varepsilon_{\mathrm{i}}=\mathrm{u}_{\mathrm{i}}-\mathrm{v}_{\mathrm{i}}$.

Given the logarithmic form of equation (1) one can derive a learning efficiency ratio, which measures the percentage of the maximum points actually received by student $i$. Assume

$$
\mathrm{Y}_{\mathrm{i}}^{*}=\mathrm{f}\left(\beta^{\prime} \mathrm{X}_{\mathrm{i}}\right)+\mathrm{u}_{\mathrm{i}}
$$

where $Y_{i}^{*}$ denotes the logarithm of the potential points a student could receive given the inputs $X_{i}$. Then the learning efficiency ratio can be calculated as

$$
E\left(\frac{Y_{i}}{Y_{i}^{*}}\right)=E\left[\exp \left(-v_{i}\right)\right]
$$

One problem with this kind of analysis is that the estimation of equation (2) only provides the estimated joint residuals $\hat{\varepsilon}_{\mathrm{i}}$. The nonnegative part of the residual, $v_{\mathrm{i}}$, can be observed only indirectly. However, Jondrow et al. (1982) have derived an explicit form for the expected value of $v_{i}$ in the case of the exponential model:

$$
\mathrm{E}\left[\mathrm{v}_{\mathrm{i}} \mid \varepsilon_{\mathrm{i}}\right]=\left(\varepsilon_{\mathrm{i}}-\theta \sigma_{\mathrm{u}}^{2}\right)+\frac{\sigma_{\mathrm{u}} \varphi\left[\left(\varepsilon_{\mathrm{i}}-\theta \sigma_{\mathrm{u}}^{2}\right) / \sigma_{\mathrm{u}}\right]}{\Phi\left[\left(\varepsilon_{\mathrm{i}}-\theta \sigma_{\mathrm{u}}^{2}\right) / \sigma_{\mathrm{u}}\right]},
$$

where $\varphi($.$) is the density of the standard normal distribution. In the next section, comparisons of the$ 
learning efficiency ratios of students with different sets of inputs $X_{i}$ before and after the re-organization of the macroeconomics course will be made on the basis of equations (4) and (5).

\section{Estimation Results}

The maximum likelihood estimates of the stochastic frontier are reported in Table 2. Confirming other studies in this area (see Durden and Ellis, 1995, Romer, 1993, and Schmidt, 1983) we found a statistically significant and negative relationship between the absenteeism in the lectures and the potential performance of the students. According to the estimated coefficient, the maximum number of points a student who missed one or more lectures could receive, is $11.3 \%$ lower if compared to a student who attended all lectures. However, attendance in the exercise course appears to have no statistically significant effect on the potential points in the final exam. Similar to Watts and Bosshardt (1991) we found a significantly positive relationship between the experience of the course instructor and the potential performance of the student. However, the estimated coefficient appears to be small, since a one semester increase in the experience of the course instructor increases the maximumnumber of points a student can receive only by $1.3 \%$. The ability of a student, measured by his high school grade, is highly significant. The estimated coefficient indicates that if the high school grade improves by one grade, the potential points of a student in macroeconomics increases by $16 \%$. Contrary to most of the reported evidence in the related literature (see Siegfried and Fels, 1979, and Becker et. al., 1990, for an overview) we could not find statistically significant gender differences in the potential performance of economics students. However, it should be noted that most of the existing studies used the results of multiple-choice exams to study gender differences in the performance of economics 
students. Our results are more consistent with the studies of Ferber (1983), Lumsden and Scott (1987) and Williams et. al. (1992) who suggest that females tend to be better than males in essay exams.

The statistically insignificant coefficient on the dummy variable indicating whether an observation is drawn from the winter survey indicates that the changes between the two semesters have no effect on the maximum points a student can potentially achieve. However, the statistically significant positive coefficient on the interaction term of attendance in the lecture and the winter semester suggests that attendance in the lecture has become less important in the winter. Furthermore, relative to the summer, learning in a group significantly decreases the potential points which could be received by a student in the winter. Finally, the mean level of the nonnegative component of the error term $\mathrm{E}[\mathrm{v}]=1 / \hat{\theta}$ is 0.254 and highly significant. The variance of the nonnegative error is 0.065 , which is $86 \%$ of the total disturbance variance of $\sigma_{u}^{2}+\sigma_{v}^{2}=0.076$. Therefore, the picture that emerges indicates only minor variation in the education production frontier across students, but a relatively substantial variation of observed points in the final exam beneath the frontier.

At the center of interest of this study is the learning efficiency of the students. Therefore, we calculated the learning efficiency ratio $\mathrm{E}\left[\frac{\mathrm{Y}_{\mathrm{i}}}{\mathrm{Y}_{\mathrm{i}}^{*}}\right]$ for each student employing the estimation results reported in Table 2 and equations (4) and (5). Table 3 contains the characteristics of the students in the first and the fourth quantile of the distribution of $E\left[\frac{Y_{i}}{Y_{i}^{*}}\right]$ for the pooled data and the two semesters, respectively. According to Table 3 the worst students achieved on average $58 \%$ of their potential points; the best students reached on average $93 \%$ of their potential. The descriptive statistics 
of the two groups of students exhibit remarkable differences with regard to their learning strategy. Compared to the students in the fourth quantile a higher fraction of the worst students have missed some lectures or courses and have never reviewed their lecture and course notes. Furthermore, a lower fraction of the students in the first quantile formed learning groups to prepare for the final exam. With respect to the other variables no clear differences between the students in the first and the fourth quantile emerges. Comparing the characteristics of the two groups of students in the summer and the winter shows that the worst and the best students are more similar in the winter. This result suggests that the introduction of the exercise book reduced the importance of attendance and continuous learning for learning efficiency.

Table 4 reports the mean efficiency ratios of students with different characteristics. According to this table the average student reached in both semesters an efficiency ratio of $80 \%$ with no difference between the two semesters. Overall, the numbers in Table 4 tend to confirm the findings of Table 3. Students who missed some lectures or courses are less efficient than those who attended regularily. Those students who reviewed their lecture and course notes are more efficient than those who never do. Finally, team-work results in a higher efficiency. In line with Table 3, the importance of attendance in the courses, steady learning of the course notes and learning in a group diminished in the winter if compared to the summer. With regard to the other variables it is interesting that those students who studied macroeconomics voluntarily were less efficient than those required to study macroeconomics in the summer, but more efficient in the winter. However, these results may be caused by the small number of students taking macroeconomics voluntarily. Students with very good high school grades tend to be less efficient compared to students with high school grades above 2 indicating 
that they use relatively more learning inputs without performing better. As in Table 3, no clear differences with regard to the other variables appear.

\section{Conclusions}

In this paper we use a stochastic frontier approach to evaluate the effects on students' learning efficiency of re-organizing the material in a principles of macroeconomics course and introducing an exercise book with very detailed solution. The empirical results show that the best students reached about $93 \%$ of their potential points in the final exam, the worst students however reached only $58 \%$ of their potential. Attendance, the ability of the student and learning in a team are the main determinants of the learning efficiency of students. Contrary to most existing empirical studies on the performance of economics students we were unable to find statistically significant gender differences. The results further indicate that the main effects of the re-organization of the lecture are a decreasing importance of students' attendance in the lectures and courses and of continuous learning of the material. 


\section{References}

Aigner, D., C. A. K. Lovell, and P. Schmidt (1977): "Formulation and Estimation of Stochastic Frontier Production Function Models," Journal of Econometrics, 6, 377-396.

Bauer, T., and K. F. Zimmermann (1997): Arbeitsbuch Makroökonomie. Berlin et. al.: SpringerVerlag.

Becker, W. E. (1997): "Teaching Economics to Undergraduates," Journal of Economic Literature, 25(2), 1347-1373.

Becker, W., W. Greene, and S. Rosen (1990): "Research on High School Economic Education," American Economic Review, 80 (2), 14-22.

Durden, G. C., and L. V. Ellis (1995): "The Effects of Attendance on Student Learning in Principles of Economics," American Economic Review, 85 (2), 343-346.

Ferber, M., B. Birnbaum, and C. Green (1983): "Gender Differences in Economic Knowledge: A Reevaluation of the Evidence," Journal of Economic Education, 14, 4-10.

Greene, W. H. (1993): “The Econometric Approach to Efficiency Analysis," in: Fried, H. O., C. A. K. Lovell, and S. S. Schmidt (eds.): The Measurement of Productive Efficiency: Techniques and Application. New York: Oxford University Press, 68-119.

Jondrow, J., C. A. K. Lovell, I. Materov, and P. Schmidt (1982): "On the Estimation of Technical Inefficiency in the Stochastic Frontier Production Function Model," Journal of Econometrics, 19 (2/3), 233-238.

Lopus, J. S., and N. L. Maxwell (1995): "Should we Teach Microeconomic Principles Before Macroeconomic Principles?" Economic Inquiry, 33 (2), 336-350.

Lumsden, K., and A. Scott (1987): “The Economics Student Reexamined: Male-Female Differences in Comprehension," Journal of Economic Education, 18, 365-375.

Romer, D. (1993): “Do Students Go to Class? Should They?' Journal of Economic Perspectives, 7 (3), 167-174.

Schmidt, R. M. (1983): "Who Maximizes What? A Study in Student Time Allocation," American Economic Review, 73 (2), 23-28.

Siegfried, J. J., and R. Fels (1979): “Research on Teaching College Economics: A Survey," Journal of Economic Literature, 17, 923-969.

Watts, M., and W. Bosshardt (1991): "How Instructors Make a Difference: Panel Data Estimates from Principles of Economic Courses," Review of Economics and Statistics, 73 (2), 336340.

Williams, M. L., C. Waldauer, and V. G. Duggal (1992): "Gender Differences in Economic Knowledge: An Extension of the Analysis," Journal of Economic Education, 23, 219-231. 
Table 1: Descriptive Statistics*

\begin{tabular}{|c|c|c|c|}
\hline Variable & Both Semester & Summer 1996 & Winter 1996/97 \\
\hline Points in Final Exam & $\begin{array}{l}61.418 \\
(15.90)\end{array}$ & $\begin{array}{l}57.981 \\
(14.86)\end{array}$ & $\begin{array}{l}64.681 \\
(16.19)\end{array}$ \\
\hline Macro compulsory & $\begin{array}{l}0.979 \\
(0.14)\end{array}$ & $\begin{array}{l}0.981 \\
(0.14)\end{array}$ & $\begin{array}{l}0.977 \\
(0.15)\end{array}$ \\
\hline Macro voluntary & $\begin{array}{l}0.021 \\
(0.14)\end{array}$ & $\begin{array}{l}0.020 \\
(0.14)\end{array}$ & $\begin{array}{l}0.023 \\
(0.15)\end{array}$ \\
\hline Missed Lectures & $\begin{array}{l}0.518 \\
(0.50)\end{array}$ & $\begin{array}{l}0.654 \\
(0.48)\end{array}$ & $\begin{array}{l}0.389 \\
(0.49)\end{array}$ \\
\hline Missed Courses & $\begin{array}{l}0.316 \\
(0.47)\end{array}$ & $\begin{array}{l}0.190 \\
(0.39)\end{array}$ & $\begin{array}{l}0.435 \\
(0.50)\end{array}$ \\
\hline Never Reviewed Lecture Notes & $\begin{array}{l}0.499 \\
(0.50)\end{array}$ & $\begin{array}{l}0.785 \\
(0.41)\end{array}$ & $\begin{array}{l}0.227 \\
(0.42)\end{array}$ \\
\hline Never Reviewed Course Notes & $\begin{array}{l}0.140 \\
(0.35)\end{array}$ & $\begin{array}{l}0.146 \\
(0.35)\end{array}$ & $\begin{array}{l}0.134 \\
(0.34)\end{array}$ \\
\hline Team-work & $\begin{array}{l}0.219 \\
(0.41)\end{array}$ & $\begin{array}{l}0.244 \\
(0.43)\end{array}$ & $\begin{array}{l}0.194 \\
(0.40)\end{array}$ \\
\hline High School Grade & $\begin{array}{l}2.324 \\
(0.59)\end{array}$ & $\begin{array}{l}2.386 \\
(0.58)\end{array}$ & $\begin{array}{l}2.265 \\
(0.60)\end{array}$ \\
\hline Number of Exams & $\begin{array}{l}3.223 \\
(0.95)\end{array}$ & $\begin{array}{l}3.102 \\
(0.94)\end{array}$ & $\begin{array}{l}3.338 \\
(0.95)\end{array}$ \\
\hline Instructors Experience & $\begin{array}{l}3.962 \\
(2.44)\end{array}$ & $\begin{array}{l}4.790 \\
(2.53)\end{array}$ & $\begin{array}{l}3.176 \\
(2.08)\end{array}$ \\
\hline Female & $\begin{array}{l}0.328 \\
(0.47)\end{array}$ & $\begin{array}{l}0.327 \\
(0.47)\end{array}$ & $\begin{array}{l}0.329 \\
(0.47)\end{array}$ \\
\hline Worked during Semester & $\begin{array}{l}0.641 \\
(0.48)\end{array}$ & $\begin{array}{l}0.644 \\
(0.48)\end{array}$ & $\begin{array}{l}0.639 \\
(0.48)\end{array}$ \\
\hline Observations & 421 & 205 & 216 \\
\hline
\end{tabular}

*: $\quad$ Standard deviations in parentheses. 
Table 2: $\quad$ Maximum Likelihood Estimates of the Stochastic Production Frontier* Dependent Variable: In (Points in Final Exam)

\begin{tabular}{|c|c|c|}
\hline Variable & Coeff. & $\begin{array}{c}\text { Asymptotic } \\
\text { T-value }\end{array}$ \\
\hline Constant & 4.636 & 70.32 \\
\hline MacroVoluntary & -0.054 & -0.75 \\
\hline Missed Lectures & -0.113 & -3.56 \\
\hline Missed Courses & 0.011 & 0.29 \\
\hline Never Reviewed Lecture Notes & -0.026 & -0.68 \\
\hline Never Reviewed Course Notes & -0.049 & -1.18 \\
\hline Team-work & 0.052 & 1.40 \\
\hline Instructors Experience & 0.013 & 2.88 \\
\hline Female & 0.007 & 0.33 \\
\hline Number of Exams & -0.012 & -1.21 \\
\hline High School Grade & -0.121 & -6.98 \\
\hline Worked During Semester & -0.035 & -1.58 \\
\hline Winter & 0.053 & 1.15 \\
\hline Missed Lectures $\cdot$ Winter & 0.135 & 2.86 \\
\hline Missed Courses $\cdot$ Winter & -0.046 & 0.92 \\
\hline Never Reviewed Lecture Notes · Winter & 0.007 & 0.13 \\
\hline Never Reviewed Course Notes $\cdot$ Winter & 0.086 & 1.30 \\
\hline Team-work $\cdot$ Winter & -0.109 & -1.98 \\
\hline$\theta$ & 3.933 & 20.15 \\
\hline$\sigma_{\mathrm{u}}$ & 0.105 & 9.29 \\
\hline $\mathrm{E}[\mathrm{v}]$ & 0.254 & - \\
\hline$\sigma^{2}[v]$ & 0.065 & - \\
\hline$\sigma^{2}[\mathrm{u}]$ & 0.011 & - \\
\hline
\end{tabular}

*: $\quad$ Observations: 423. 
Table 3: Descriptive Statistics of Students in the First and the Fourth Quantiles of the Distribution of $\mathbf{E}\left[\frac{\mathbf{Y}_{\mathbf{i}}}{\mathbf{Y}_{\mathbf{i}}^{*}}\right] *$

\begin{tabular}{lcccccc}
\hline \multicolumn{1}{c}{ Variable } & \multicolumn{3}{c}{ First Quantile } & & \multicolumn{3}{c}{ Fourth Quantile } \\
& Both & Summer & Winter & Both & Summer & Winter \\
\hline Mean Efficiency Ratio & 0.582 & 0.583 & 0.567 & 0.934 & 0.932 & 0.934 \\
Points in Final Exam & 42.204 & 40.327 & 43.061 & 77.467 & 72.714 & 81.927 \\
Macro Voluntary & 0.029 & 0.041 & 0.020 & 0.028 & 0.000 & 0.055 \\
Missed Lectures & 0.592 & 0.694 & 0.469 & 0.505 & 0.571 & 0.436 \\
Missed Courses & 0.369 & 0.265 & 0.429 & 0.299 & 0.179 & 0.418 \\
Never Reviewed Lecture Notes & 0.553 & 0.878 & 0.245 & 0.514 & 0.768 & 0.236 \\
Never Reviewed Course Notes & 0.175 & 0.204 & 0.143 & 0.140 & 0.125 & 0.146 \\
Team-work & 0.204 & 0.225 & 0.204 & 0.243 & 0.250 & 0.236 \\
Instructors Experience & 3.845 & 5.000 & 3.020 & 4.047 & 4.786 & 3.236 \\
Female & 0.311 & 0.327 & 0.286 & 0.308 & 0.232 & 0.382 \\
Number of Exams & 3.359 & 3.327 & 3.367 & 3.262 & 3.071 & 3.473 \\
High School Grade & 2.357 & 2.337 & 2.335 & 2.342 & 2.454 & 2.220 \\
Worked During Semester & 0.670 & 0.694 & 0.633 & 0.654 & 0.679 & 0.618 \\
Observations & 103 & 49 & 49 & 107 & 56 & 55 \\
\hline \hline
\end{tabular}

*: $\quad$ See formula (4) and (5) and text for a detailed explanation. 
Table 4: $\quad$ Estimated Learning Efficiency Ratios*

\begin{tabular}{|c|c|c|c|c|c|c|c|}
\hline & & \multicolumn{2}{|c|}{ Both Semester } & \multicolumn{2}{|c|}{ Summer 1996} & \multicolumn{2}{|c|}{ Winter 1996/97 } \\
\hline & & Mean & (S.D.) & Mean & (S.D.) & Mean & (S.D.) \\
\hline Mean Student & & 0.801 & $(0.154)$ & 0.801 & $(0.157)$ & 0.800 & $(0.152)$ \\
\hline Macro Voluntary & & 0.732 & $(0.257)$ & 0.562 & $(0.299)$ & 0.868 & $(0.116)$ \\
\hline Macro Compulsory & & 0.802 & $(0.151)$ & 0.806 & $(0.150)$ & 0.799 & $(0.153)$ \\
\hline \multirow[t]{2}{*}{ Missed Lectures } & Yes & 0.786 & $(0.178)$ & 0.790 & $(0.176)$ & 0.780 & $(0.182)$ \\
\hline & No & 0.816 & $(0.122)$ & 0.822 & $(0.108)$ & 0.813 & $(0.129)$ \\
\hline \multirow[t]{2}{*}{ Missed Courses } & Yes & 0.775 & $(0.197)$ & 0.733 & $(0.245)$ & 0.793 & $(0.171)$ \\
\hline & No & 0.812 & $(0.129)$ & 0.817 & $(0.123)$ & 0.806 & $(0.136)$ \\
\hline \multirow[t]{2}{*}{ Never reviewed Lecture Notes } & Yes & 0.790 & $(0.165)$ & 0.791 & $(0.166)$ & 0.784 & $(0.161)$ \\
\hline & No & 0.812 & $(0.142)$ & 0.837 & $(0.108)$ & 0.805 & $(0.150)$ \\
\hline \multirow[t]{2}{*}{ Never reviewed Course Notes } & Yes & 0.773 & $(0.197)$ & 0.753 & $(0.228)$ & 0.794 & $(0.160)$ \\
\hline & No & 0.805 & $(0.146)$ & 0.809 & $(0.140)$ & 0.801 & $(0.151)$ \\
\hline \multirow[t]{2}{*}{ Team-work } & Yes & 0.822 & $(0.119)$ & 0.830 & $(0.106)$ & 0.812 & $(0.133)$ \\
\hline & No & 0.795 & $(0.162)$ & 0.792 & $(0.169)$ & 0.797 & $(0.157)$ \\
\hline \multirow[t]{3}{*}{ High School Grade } & 1 & 0.721 & $(0.151)$ & 0.726 & $(0.184)$ & 0.717 & $(0.140)$ \\
\hline & 2 & 0.804 & $(0.150)$ & 0.799 & $(0.154)$ & 0.808 & $(0.147)$ \\
\hline & 3 & 0.795 & $(0.172)$ & 0.782 & $(0.215)$ & 0.772 & $(0.174)$ \\
\hline \multirow[t]{3}{*}{ Number of Exams } & 1 & 0.826 & $(0.061)$ & 0.819 & $(0.168)$ & - & - \\
\hline & 2 & 0.824 & $(0.128)$ & 0.856 & $(0.089)$ & 0.791 & $(0.153)$ \\
\hline & 3 & 0.804 & $(0.154)$ & 0.799 & $(0.151)$ & 0.811 & $(0.157)$ \\
\hline \multirow[t]{3}{*}{ Instructors Experience } & 1 & 0.823 & $(0.124)$ & 0.808 & $(0.129)$ & 0.847 & $(0.116)$ \\
\hline & 3 & 0.780 & $(0.156)$ & 0.789 & $(0.132)$ & 0.778 & $(0.160)$ \\
\hline & 5 & 0.806 & $(0.159)$ & 0.801 & $(0.166)$ & 0.817 & $(0.146)$ \\
\hline Female & & 0.808 & $(0.138)$ & 0.808 & $(0.125)$ & 0.808 & $(0.150)$ \\
\hline Male & & 0.797 & $(0.162)$ & 0.798 & $(0.170)$ & 0.796 & $(0.154)$ \\
\hline \multirow[t]{2}{*}{ Worked During Semester } & Yes & 0.801 & $(0.154)$ & 0.801 & $(0.162)$ & 0.801 & $(0.146)$ \\
\hline & No & 0.800 & $(0.155)$ & 0.801 & $(0.147)$ & 0.799 & $(0.163)$ \\
\hline
\end{tabular}

*: $\quad$ The ratios are computed as E[exp(-v)] using the estimation results in Table 2 and equations (4) and (5) in the text. All numbers are based on group means. 